\begin{tabular}{c} 
International Journal of Engineering \& Technology, $7(3.21)(2018) 93-101$ \\
International Journal of Engineering \& Technology \\
SPC \\
Website: $\frac{w w w . s c i e n c e p u b c o . c o m / i n d e x . p h p / I J E T}{2 \text { Research paper }}$ \\
\hline
\end{tabular}

\title{
The Disclosure of Audited Fund Campaign Accounting in Indonesia
}

\author{
Lita Kusumasari ${ }^{1 *}$ \\ ${ }^{1}$ STIE YKPN School of Business, Yogyakarta, Indonesia \\ *Corresponding author E-mail: Lkusumasari@yahoo.com
}

\begin{abstract}
After long history on democracy, Indonesia formed General Elections Commission (Indonesia: Komisi Pemilihan Umum (KPU)) in 1999. KPU is the legitimate body to organize elections in Indonesia. The responsibilities of KPU are deciding the parties that can compete on elections, ruling the voting and the results of seat won for legislatives, president, and mayors in Indonesia. Including the task is set up regulation for campaign and fund campaign accounting. The fund campaign reports are audited using 15 agreed upon procedures by the auditors. The research findings are 42 mistakes from 11 political parties. Only one political party does not make the mistake. The weakness comes from many forms, such as: transpose error, not following the KPU rule no. 17, 2013, the donation is not supported by legal identity, the donation without legal identity is not given back to country, the fund is not placed in special account before used, the candidates submitted fund campaign report without supporting documents, there is error on placing expenditure segment, the sum error, and there is no consistency between one report to another report. The findings on fund campaign reporting from the political parties are analyzed by goodness of fit test (chi-square). The research found that the total mistakes on fund campaign reporting by political parties are same. Based on the result and weakness, KPU need to make it better understanding to political parties by doing training and assisting. The standards of implementation on KPU regulation need to impose so that the quality of fund campaign accounting could be improved. The time frame to report should also be considered.
\end{abstract}

Keywords: audited fund campaign report; campaign; KPU regulation

\section{Introduction}

Indonesia has been doing election since 1955. It is a long history from authoritarian rule until finally democracy. The changing based on politics circumstances on every era, but corruption being alleged before 1998. The issue made people doing big riot in 1998 to step down the legitimate president. Around that year, people did not trust on politics and economics. Indonesia was trying to change the mistrust. There were only three parties on Suharto era (before 1998) which were Golkar, PDIP, and PPP. The ruling party was Golkar. As a dominance party, Golkar had economic privileges and strategic position on government. The other two opposition parties had limited activities. The effort to bring back trust is not so easy(1).

In Indonesia, corruption allegations became serious issue that led to step down of President Suharto in 1998. After long history on democracy, Indonesia formed General Elections Commission (Indonesia: Komisi Pemilihan Umum (KPU)) in 1999. KPU is the legitimate body to organize elections in Indonesia. The responsibilities of KPU are deciding the parties that can compete on elections, ruling the voting and the results of seat won for legislatives, president, and mayors in Indonesia. Including the task is set up regulation for campaign and fund campaign accounting(2).

The general election had been arranged by government before 1998. The independency had been questions. To bring back the trust on general election, KPU has an important role. It is independence body to set up the new era on Indonesia's general election in 1999. KPU enacted rule on regulating parties and financing campaign. The parties whose compete become more than three Those all have the same position under the new law. The political party has to follow the KPU Rule no. 17, 2013 regarding fund campaign accounting and reporting(3). The rule is basically set up regulation on donation source and limitation amount, the legal types of expenditure, the report on fund campaign accounting and the audit.

Although there is law relating to general elections and political parties but the enforcement of party and campaign finance laws has been seen so far as ineffective. The audit as a guardian of enact rule not reveal enough of the truth. It has been noted only on significant finance violations. The ineffective is not solely the mistake on audit because the political parties have inadequate accounting systems that make credible auditing difficult.

Member of Indonesian Institute of Certified Public Accountants (IAPI) conduct audit for campaign fund reporting. It is called audit by KPU. The audit is based on agreed upon procedures and compliance. It is regulated on KPU Regulation No. 24, 2013(4) and KPU Regulation No. 12, 2014(5). The complete guidance is on the KPU Decision Letter No. 368, 2014(6). The engagement is done in 30 days since the political party submitted the fund campaign reporting to KPU. KPU has the authority to select the certified public accountant based on regulation.

Agree upon procedures are not audit or review based on the framework for assurance engagements by IAPI. It is in related services framework (SJT 4400). There are 15 procedures for fund campaign auditing. Auditors limited their work only on revenue and expenses reporting of political party not include the candidate fund campaign reporting. The auditors will not give assurance. They only report factual finding based on agree upon procedures 
and stated compliance. KPU engaged auditors to check confirmation on practical with related campaign laws. There are two reporting by auditors (finding of agreed upon procedures and compliance of campaign laws).

The fund campaign reporting is important. It is resemble of accountability and transparency. The report shows the revenue from the donors and the expense incurred. Voters can decide whether the political parties would be corrupt in the future or not based on the revenue and spending. Voters may related campaign accounting reporting with corruption based on the amount spending and the source. The bigger the amount spending without good credibility of the candidates will lead to corruption and collusion in the future. Candidates have to pay back the support.

Based on the premise, the research will conduct several aims:

1. To summarize the factual finding on fund campaign reporting in Indonesia in 2014.

2. To find out the weaknesses of fund campaign reporting.

3. To see whether there are finding differences among political parties.

\section{Literature Review}

The agency theory explains the relationships between principals and agents in the business. Management is agent. Owner is principal. The theory stated that management may have different interest with the principal toward the business. This may happen because agents have their own best interest that may not align with principals. The governance mechanisms may limit agent's interest behavior(7). The theory is used on this campaign issues. Political party stands like management. The principal is the voters who want to see the responsibility on fair campaign and fund campaign reporting $(8)$. The goal is no more corruption and money politics. The political parties are on the other hand having pressure to be success on the number of seat won. Although there is rule enact toward fair campaign and fund campaign reporting, the political parties try to adapt and to use for their advantage(9). KPU as regulator need to enact the law that campaign is fair and reported as transparent as the truth. Based on that, the accountability will rise and good governance for the internal party will be conducted. People trust will be better. Several things as legislative need to be done:

1. Limitation on fund campaign: The set up limit of donation based on reducing the influence between large donors and small donors.

2. Disclosure: The donators need to declare the source and the amount of fund campaign. Public has access to monitor and judge the interest of donators. Public will see whether the donation would impair the independence of the party.

3. Public source is monitored for being used in the campaign The donation should come from legal sources, thus in the future would reduce corruption because of payback fund for campaign.

4. External audit becomes mandatory. The field work is not limit only on necessary items but all. The fund campaign reporting is public information that is free from bias and irregularities. Public can read and interpret the audited fund campaign accounting to value the objectivity.

\subsection{The Enforcement}

The study by International Foundation for Election Systems (IFES) in 1999 revealed that the law of enforcement in political parties was weak. The weaknesses were contributed by the accounting system and the audit process(10). The violation filed toward fund campaign accounting in 1999 elections, did not follow up and process properly(1). There are four Indonesian political parties not fully compliance with fund campaign law in 2014 Three of them have donation findings, such as no legal identity supported and different identity between documents(11). People and political party still bargain with the law.

\subsection{The Audit}

In United States, total cost of election is increasing $70 \%$ from 2000 to 2008 . The biggest donation comes from finance institution, insurance and real estate. The 800 groups are reported to influence the winner outcome in US. The candidates may not directly correlate with this expense but the role of outside groups has significantly emerged. The biggest expenditure is independent, such as advertising. It is so hard to find the true motive inside the campaign source, so that the voter should be wise. Audited reported is a tool for political party to be accountable, transparent, and integrity. Transparency is important because voters can judge political messages if they know meaningfully where the spending is coming from(12).

The level of knowledge, quality audit, and the audit report are difference between political parties, KPU and public accountants(13). The research is using cluster random sampling for political parties, general election commissions, and public auditors in Madiun. Questionnaires are distributed with Likert scale and evaluated using multivariate of analysis (Manova).

The submission rate for fund campaign reporting is high. There is $92 \%$ on time submission of fund campaign report from 5 political parties in Bali that get the highest electoral votes. On time submission is looked at on four indicators of submission date set by General Election Commission. It is tested using chi-square with purposive sampling method. The failure is $8 \%$ to comply with on time submission because they don't win the legislative seats(14).

There is challenge on audit of fund campaign reporting from the limited auditors comparing with the entities served and limited time to finish audit work. Based on the conditions, there is premise that it would make reducing on audit quality. It is explanatory research using auditor focus of control and locus of control integrated with commitment and time limitation on a political party. The result shows there is reducing on audit quality(15).

\subsection{Fund Campaign}

Law No. 8, 2012 on General Election is not giving political equality for the legislative candidates. There is negative impact on fund campaign due to the powerful fund will beat the least campaign fund(16). Political parties should be restricted on cash funding in campaign(17). The study showed that public has negative reaction to candidate with campaign support on their own compare to candidate with having public support legally(18).

\subsection{Voters}

Voter chooses the candidates based on many things. Parents, religion, older age, religion advice and neighbors influenced the political voters. They would vote based on rational thought such as figures candidates, ideas or program campaign and integrity(19). Money was predicted as playing role to the success of candidates. Money is not the only one success in Japan, South Korea and Taiwan(20).

In the digital era, to attract the voters, candidates are playing many platforms. Facebook is the highest social media application used to attract the voters on a campaign of political parties among Instagram, Path, and others. Political party which used the social media as tool for campaign won the legislative elections(21). It is an edge era while candidates measure their election vote by doing political polling too. At the first time, political polling was acting as a tracker of voters' preferences but later on change to be powerful political device(22). 


\subsection{Fund Campaign Regulations}

Indonesia is developing countries in South East Asia, growing together with all other countries in that region. As member of Association of South-East Asian Nations (ASEAN), Indonesia is having the same history toward colonization to independence. Doing comparison rule on fund campaign regulations between those countries will help to understand the position of Indonesia (see table 1).

Table 1: Fund Campaign Regulation on ASEAN countries

\begin{tabular}{|l|l|l|l|l|l|l|}
\hline No. & Rule & Indonesia & Cambodia & Malaysia & Philippines & Thailand \\
\hline 1 & Regulation for political parties & Yes & Yes & Yes & No & Yes \\
\hline 2 & Regulation for fund campaign & Yes & Yes & Yes & Yes & Yes \\
\hline 3 & Limit on donation & Yes & No & No & No & No \\
\hline 4 & Limit on expenditure & No & No & Yes & Yes & Yes \\
\hline 5 & Source of donation: & & & & & \\
\hline 6 & Business & Yes & Yes & Yes & Yes & Yes \\
\hline 7 & Unions & Yes & No & Yes & Yes & Yes \\
\hline 8 & Foreign & No & No & Yes & Yes & No \\
\hline 9 & Disclosure source of donation & Yes & No & No & No & Yes \\
\hline 10 & The state provide funding to political parties & Yes & No & No Available Data & No & Yes \\
\hline 11 & Financial audit of political parties & Yes & Yes & Yes & No & Yes \\
\hline 12 & Audit result available to public & Yes & No & No Available Data & No & Yes \\
\hline 13 & Has an Anti-Corruption Commission & Yes & No & Yes & Yes & Yes \\
\hline 14 & Has an Independent Election Commission & Yes & Yes & $\begin{array}{l}\text { Yes but not really } \\
\text { independent }\end{array}$ & Yes & Yes \\
\end{tabular}

Regulation for fund campaign has been ruled in Indonesia, Cambodia, Malaysia, Philippines, and Thailand. The regulation for political parties is not set up yet in Philippines. Indonesia is step up on limitation of donation while others have not been ruled yet. In the other part, Indonesia and Cambodia have no limitation on expenditure while others did. The same with source of donation, again Indonesia, Cambodia, and Thailand strictly prohibited foreign donation. Indonesia and Thailand rule the disclosure of donation. Only Philippines is not doing audit of political party. Indonesia and Thailand are better for transparency because audit result is available for public. Cambodia is the only country that has no anticorruption commission. All countries have election commission.

\subsection{Research Gap and Contribution}

The coverage research is audited fund campaign reports from all political parties in Indonesia in 2014. The same with Hakim research (2014) but different detail coverage on agreed upon procedures and compliance. The coverage is population that make it different with other research which take only one region in Indonesia $(14,15)$.

From the metodology, this is explanatory research for analyzed the agreed upon procedures and compliance like others do (15) (11) (21) (22) $(17)(14,16)$. The Chi square analysis is used for testing the submission date compliance(14). Multivariate of analysis is used to test expectation gap of knowledge audit, quality audit, and responsibility of audit report(13). The difference of using chi square analysis as quantitative method is the object of measurement that is the differences mistake between political parties. None scholar is measure this.

\section{Research Methodology}

There are two steps for the research. First, the study gathers data collected from 12 political parties (population). The data are audited fund campaign reports to analyze the fund campaign accounting. The audited fund campaign report is reported on 15 procedures by the auditors based on the regulations. The research note and count the findings and disclosure regarding this issues. The same procedure does for the compliance statements. The compliance audit is reviewed based on 11 compliance items. The audited fund campaign reports are downloaded from Indonesia general election website (www.kpu.go.id).

Second phased, after having summary of the mistakes on the fund campaign reporting, then the quantitative data is analyzing by the goodness of fit test (chi-square) from the political parties, with the hypothesis

Ho $=$ There are no difference mistakes between all political parties regarding the fund campaign report.

$\mathrm{Ha}=$ There are difference mistakes between all political parties regarding the fund campaign report.

\subsection{Agreed Upon Procedures}

Based on those backgrounds, the research will conduct on the result. We get all audited fund campaign accounting from KPU website. There are 12 audited fund campaign report statement. The auditors based on agree upon procedures have been doing audit. It has been divided to 15 questions and statements. The public accountants are not issue opinion. They just state that the finding based on the law is right or wrong. If it is wrong, the auditor will ask $\mathrm{n}$ write the reasons. The appointed auditors have been confirmed with the regulation sets on them such as the independency, integrity, and the administrative procedures by KPU. The political parties and auditors can be seen on table 2 .

Table 2: Political Parties and Auditors

\begin{tabular}{|c|l|l|}
\hline No & \multicolumn{1}{|c|}{ Political Parties } & \multicolumn{1}{|c|}{ Auditors } \\
\hline 1 & Partai Nasional Demokrat (Nasdem) & Usman \& Rekan \\
\hline 2 & Partai Kebangkitan Bangsa (PKB) & Yanuar \& Riza \\
\hline 3 & Partai Keadilan Sejahtera (PKS) & $\begin{array}{l}\text { Drs. Thomas, } \\
\text { Blasius, Widartoyo } \\
\text { \& Rekan }\end{array}$ \\
\hline 4 & $\begin{array}{l}\text { Partai Demokrasi Indonesia Per- } \\
\text { juangan (PDIP) }\end{array}$ & $\begin{array}{l}\text { Teguh Heru \& } \\
\text { Rekan }\end{array}$ \\
\hline 5 & $\begin{array}{l}\text { Partai Golongan Karya (Golkar) } \\
\text { Prs. Abdulrahman } \\
\text { Hasan Salipu }\end{array}$ \\
\hline 6 & $\begin{array}{l}\text { Partai Gerakan Indonesia Raya } \\
\text { Gerindra) }\end{array}$ & $\begin{array}{l}\text { Drs. Henry } \\
\text { Sugeng }\end{array}$ \\
\hline 8 & Partai Amanat Nasional (PAN) Budi \\
\hline 9 & Partai Persatuan Pembangngan (PPP) & $\begin{array}{l}\text { Sardjono } \\
\text { Sudharnoto }\end{array}$ \\
\hline 10 & Partai Hati Nurani Rakyat (Hanura) & $\begin{array}{l}\text { Sriyadi, Elly \&unarjo \& } \\
\text { Rekan }\end{array}$ \\
\hline 11 & Partai Bulan Bintang (PBB) & $\begin{array}{l}\text { Made Sudarma, } \\
\text { Thomas, Dewi }\end{array}$ \\
\hline 12 & $\begin{array}{l}\text { Partai Keadilan dan Persatuan Indo- Rakhma- } \\
\text { nesia (PKPI) }\end{array}$ & $\begin{array}{l}\text { Wisnu B. Soewito } \\
\text { \& Rekan }\end{array}$ \\
\hline
\end{tabular}

The fund campaign reports are submitted to KPU in many forms. It is started by the fund need to put on special account solely for campaign. The political parties have to submit the evidence of the 
opening balance of special account (January, 11, 2013). Later on the political parties give the initial statement of fund campaign reporting (March 2, 2014). After that, the campaign time started. Political parties have to submit another report in two phased. The reports are statement of donation on fund campaigns. The statement of donation is submitted twice in different periods (December 27, 2013 and March 2, 2014). A week after campaign is finished, the fund campaign accounting reporting is submitted to KPU on April 24, 2014. The fund campaign accounting reporting consists of two parts. The first part is revenue and expenditure of fund campaign reporting by political parties and the second part is fund campaign reporting by candidates.

Auditors are working only on revenue and expenditure of fund campaign reporting by the political parties. They are not doing audit on fund campaign reporting by candidates. It is limited due to the time frame and audit fee. It is not possible to coverage all the candidates' fund campaign accounting. The candidate fund campaign has been included in the campaign fund of political parties. The campaign fund of political parties can be seen on table 3.

Table 3: Campaign Fund,Indonesian Rupiah (Rp)

\begin{tabular}{|r|l|r|r|r|}
\hline No & Political Party & \multicolumn{1}{|c|}{ Income (1) } & \multicolumn{1}{c|}{ Expenses (2) } & \multicolumn{1}{c|}{ Balance (1-2) } \\
\hline \hline 1 & Gerindra & $455,084,529,251.00$ & $455,031,140,324.00$ & $53,388,927.00$ \\
\hline 2 & PDIP & $395,624,661,528.00$ & $404,713,519,587.00$ & $(9,088,858,059.00)$ \\
\hline 3 & PKS & $121,242,748,218.04$ & $121,754,244,675.64$ & $(511,496,457.60)$ \\
\hline 4 & Golkar & $402,190,015,335.00$ & $402,188,780,715.00$ & $1,234,620.00$ \\
\hline 5 & PKPI & $52,962,935,981.00$ & $8,078,119,453.00$ & $44,884,816,528.00$ \\
\hline 6 & PBB & $71,408,342,631.00$ & $69,402,006,849.00$ & $2,006,335,782.00$ \\
\hline 7 & PD & $309,220,608,865.00$ & $307,365,234,277.00$ & $1,855,374,588.00$ \\
\hline 8 & PKB & $239,100,482,858.00$ & $60,745,150,312.00$ & $178,355,332,546.00$ \\
\hline 9 & Nasdem & $216,417,962,454.00$ & $224,932,339,866.00$ & $(8,514,377,412.00)$ \\
\hline 10 & PAN & $272,016,228,663.00$ & $271,915,628,687.00$ & $100,599,976.00$ \\
\hline 11 & Hanura & $374,392,186,059.00$ & $365,736,434,263.00$ & $8,655,751,796.00$ \\
\hline 12 & PPP & $157,175,307,559.00$ & $155,792,164,906.00$ & $1,383,142,653.00$ \\
\hline \multicolumn{7}{|r|}{ TOTAL } & $\mathbf{3 , 0 6 6 , 8 3 6 , 0 0 9 , 4 0 2 . 0 4}$ & $\mathbf{2 , 8 4 7 , 6 5 4 , 7 6 3 , 9 1 4 . 6 4}$ & $\mathbf{2 1 9 , 1 8 1 , 2 4 5 , 4 8 7 . 4 0}$ \\
\hline
\end{tabular}

Source $=$ summary of research data

The fund campaign reporting is based on KPU Regulation no. 17 2013. The political parties have to submit 13 reports. First, the political party opened the special campaign bank account (RKDK) All the funds had to deposit there before spending on campaign expense. There is limitation for donation. Maximum for personal donation is Rp1 Billion and for entities is Rp7.5 Billion. The donations are cash, goods, or services based on fair value. All donators have to submit donation representation letter along with the copy of identity. The political parties have to report the donations on the donation campaign revenue report (LPSDK). It reported twice to KPU.

All the expenses are recorded and reported on the activities and expenses (DAPDK). The expenses are categorized as operational expenses, capital expenditures, and other expenses. All recorded based on fair value. Both LPSDK and DAPDK will have detail records on revenues and expenses of fund campaign report (LPPDK). It made twice as the beginning campaign time (as initial balance) and last as final report after campaign time finished.

The candidates have to report their fund campaign on revenue and expenses candidates. They submit in separate document. The information of candidate fund campaign has to be consolidated on revenue and expenses of fund campaign report by political party (LPPDK).

\section{Result and Findings}

\subsection{Audited Fund Campaign Reporting}

The fund campaign report has to be legal, accountable, and transparent. Based on that premise, KPU appointed auditors to audit the report. KPU makes collaboration with IAPI. It is not possible for doing regular audit due to special characteristics of fund campaign reporting. The accounting standard of fund campaign accounting is quite different with regular accounting. Fund campaign accounting is blend between cash basis and accrual. Fund campaign accounting mixed the reports between statement of position and income statement. Based on the special cases above then agreed upon procedures is taken as approach to audit. The agreed upon procedures are divided into five segments and 15 procedures. The five segments are set up by KPU based on the KPU Decision Letter No. 368, 2014 (see table 4).

Table 4: The Agreed Upon Procedures

\begin{tabular}{|c|c|c|}
\hline No & \multicolumn{2}{|c|}{ Agree Upon Procedures } \\
\hline A & \multicolumn{2}{|c|}{ GENERAL } \\
\hline & 1 & $\begin{array}{l}\text { Record the receipt letter of fund campaign reporting and } \\
\text { supporting documents }\end{array}$ \\
\hline & 2 & $\begin{array}{l}\text { a. Tracing the revenue and expenses on special campaign } \\
\text { bank account (RKDK) to revenue and expenses of } \\
\text { fund campaign report (LPPDK). } \\
\text { b. Record as finding for any transactions on RKDK but } \\
\text { not recorded on LPPDK }\end{array}$ \\
\hline $\mathrm{B}$ & \multicolumn{2}{|r|}{ SPECIAL CAMPAIGN BANK ACCOUNT } \\
\hline & 3 & $\begin{array}{l}\text { Specify that special campaign bank account has to open on } \\
\text { general bank. }\end{array}$ \\
\hline & 4 & $\begin{array}{l}\text { Specify that name of the special bank account is political } \\
\text { party. }\end{array}$ \\
\hline $\mathrm{C}$ & \multicolumn{2}{|r|}{ FUND CAMPAIGN DONATION } \\
\hline & 5 & $\begin{array}{l}\text { a. Check the classification of revenues on the donation } \\
\text { campaign revenue report (LPSDK) and LPPDK as } \\
\text { 1) Political Party } \\
\text { 2) Candidates } \\
\text { 3) Others Donation (personal, organization, and en- } \\
\text { tities) } \\
\text { 4) Others (liability and discount) } \\
\text { b. Check for every donation should have donation repre- } \\
\text { sentation letter }\end{array}$ \\
\hline & 6 & Count and recheck the sum of donation on LPSDK \\
\hline & 7 & Compare the value of donation between LPSDK and LPPDK \\
\hline & 8 & Recount the sum of donation for every donator \\
\hline & 9 & Check the legality of every donation \\
\hline & 10 & $\begin{array}{l}\text { a. Check for every donation recorded on LPSDK is en- } \\
\text { closed with donation representation letter and copy } \\
\text { identity } \\
\text { b. Check that all donations have been recorded on RKDK } \\
\text { c. Send positive confirmation to donators } \\
\text { d. Check for non cash donations are recorded based on } \\
\text { fair value } \\
\text { e. Check the supporting documents for fair value }\end{array}$ \\
\hline $\mathrm{D}$ & \multicolumn{2}{|r|}{ FUND CAMPAIGN EXPENDITURE } \\
\hline & 11 & $\begin{array}{l}\text { Check the classification of expenses on the activities and } \\
\text { expense of campaign report (DAPDK) and LPPDK }\end{array}$ \\
\hline & 12 & Count and recheck the sum of expenses on DAPDK \\
\hline & 13 & Compare the value of expenses on DAPDK and LPPDK \\
\hline & 14 & $\begin{array}{l}\text { a. Check for every expenses recorded on DAPDK is en- } \\
\text { closed with supporting documents and recorded on } \\
\text { RKDK } \\
\text { b. Check the accuracy of expenses recording (date, value, } \\
\text { recipients, and detail transactions) } \\
\text { c. For non cash transactions are recorded based on fair } \\
\text { value } \\
\text { d. Check the legality discount taken }\end{array}$ \\
\hline $\mathrm{E}$ & \multicolumn{2}{|r|}{ THE POLITICAL PARTY REPRESENTATION LETTER } \\
\hline & 15 & $\begin{array}{l}\text { Get the political party representation letter that political party } \\
\text { has submit all necessary documents }\end{array}$ \\
\hline
\end{tabular}

The result of agreed upon procedures are summarized on table 5 . Auditors find out findings on almost all parties except Partai Gerakan Indonesia Raya (Gerindra). The minimum finding is one (Partai Golongan Karya) and maximum is ten (Partai Bulan Bintang). Total findings are 42 from 11 political parties.

Partai Nasional Demokrat gets 6 findings for inconsistency between reporting, there are no copies of identities for donators, the inconsistency on expense categories and double counting. Partai Kebangkitan Bangsa gets 2 findings on missing the supporting documents for donations and not record interest revenue and administration fee. Partai Keadilan Sejahtera gets 4 findings on spending directly from donation (not through special campaign 
bank account), mistakes on counting, no supporting document for donations, and difficulty to judge fair value. Partai Demokrasi Indonesia Perjuangan gets 2 findings solely on no basis for fair value in revenue and expenses. Partai Golongan Karya gets only 1 finding on misplace the cash donation recording as good donation. Partai Demokrat gets 4 findings based on no supporting document for donation, inconsistency between DLPSK and LPPDK, and 177 candidates do not submit fund campaign reporting. Partai Amanat Nasional gets 4 findings on donators not support by copy of identity, spending directly from donation (not through special campaign bank account), not giving back illegal donation to country and no answer on all positive confirmations. Partai Persatuan Pembangunan gets 4 findings on mixed between revenue and expenses on interest revenue and tax, inconsistency between DLPSK and LPPDK, double counting and mistakes on recording. Partai
Hati Nurani Rakyat gets 3 findings on spending directly from donation (not through special campaign bank account), donators not support by copy of identities, and inconsistencies on date recording.

The maximum findings are Partai Bulan Bintang that gets 10 findings. There is no supporting document for one donation, no detail record for accommodation and socialization expense, spending directly from donation (not through special campaign bank account), no receiving report for flags donation, inconsistency between DAPDK and LPPDK, transpose error, the expenses are not categorized as classified on DAPDK. Partai Keadilan dan Persatuan Indonesia gets 2 findings on expense and revenue are not recorded on RKDK and the candidates' expense are not recorded on LPPDK.

Table 5: Finding on Agreed Upon Procedures

\begin{tabular}{|c|c|c|c|c|}
\hline No & Political Parties & $\begin{array}{l}\text { Procedures } \\
\text { No. }\end{array}$ & Findings & $\begin{array}{l}\text { Total } \\
\text { Findings }\end{array}$ \\
\hline \multirow[t]{4}{*}{1} & \multirow[t]{4}{*}{$\begin{array}{l}\text { Partai Nasional Demo- } \\
\text { krat (Nasdem) }\end{array}$} & 7. & $\begin{array}{l}\text { There is difference amount between donations in DLPSK and LPPDK. The difference } \\
\text { is Rp61.197 Billion }\end{array}$ & \multirow[t]{4}{*}{6} \\
\hline & & 10. & $\begin{array}{l}\text { a. Some of personal donators do not enclosed copies of identities. } \\
\text { b. Some of entities donators do not enclosed copies of tax payer numbers. }\end{array}$ & \\
\hline & & 11. & There is difference on expense categories between DAPDK and LPPDK. & \\
\hline & & 13. & $\begin{array}{l}\text { a. There is difference amount between expense in DAPDK and LPPDK. The differ- } \\
\text { ence is Rp53 Billion } \\
\text { b. There is double counting in expense }\end{array}$ & \\
\hline 2 & $\begin{array}{l}\text { Partai Kebangkitan } \\
\text { Bangsa (PKB) }\end{array}$ & 2. & $\begin{array}{l}\text { a. There is no supporting documents for donations on LADK and RKDK } \\
\text { b. Revenue interest on saving and administration bank fee are not recorded }\end{array}$ & 2 \\
\hline \multirow[t]{3}{*}{3} & \multirow{3}{*}{$\begin{array}{l}\text { Partai Keadilan Sejahtera } \\
\text { (PKS) }\end{array}$} & 2. & Some transactions are cash and not included in RKDK. & \multirow[t]{3}{*}{4} \\
\hline & & 8. & $\begin{array}{l}\text { There is difference between the sum of accumulation of donations and recorded (mis- } \\
\text { take on counting). }\end{array}$ & \\
\hline & & 10. & $\begin{array}{l}\text { a. The donators do not enclosed copies of identities. } \\
\text { b. There is difficulty to value service donation based on fair value because no support- } \\
\text { ing document. }\end{array}$ & \\
\hline \multirow[t]{2}{*}{4} & \multirow[t]{2}{*}{$\begin{array}{l}\text { Partai Demokrasi Indo- } \\
\text { nesia Perjuangan (PDIP) }\end{array}$} & 10. & $\begin{array}{l}\text { There is difficulty to value donation based on fair value because no supporting docu- } \\
\text { ment. }\end{array}$ & \multirow[t]{2}{*}{2} \\
\hline & & 14. & $\begin{array}{l}\text { There is difficulty to value expense based on fair value because no supporting docu- } \\
\text { ment. }\end{array}$ & \\
\hline 5 & $\begin{array}{l}\text { Partai Golongan Karya } \\
\text { (Golkar) }\end{array}$ & 5. & Cash donation (Rp1 Billion) is recorded as good donation. & 1 \\
\hline 6 & $\begin{array}{l}\text { Partai Gerakan Indonesia } \\
\text { Raya (Gerindra) }\end{array}$ & - & No finding & - \\
\hline \multirow[t]{4}{*}{7} & \multirow[t]{4}{*}{ Partai Demokrat (PD) } & 5. & $\begin{array}{l}\text { One donator does not give donation letter and copy of identity. } \\
\text { The donation is Rp5 Million and has been given back to the country. }\end{array}$ & \multirow[t]{4}{*}{4} \\
\hline & & 7. & $\begin{array}{l}\text { There is difference amount between donations in DLPSK and LPPDK. The difference } \\
\text { is Rp13 Million. }\end{array}$ & \\
\hline & & 10. & One entity donator does not enclosed copies of tax payer number and entities permit & \\
\hline & & 14. & There are 177 candidates that do not submit revenues and expenses on fund campaign. & \\
\hline 8 & $\begin{array}{l}\text { Partai Amanat Nasional } \\
\text { (PAN) }\end{array}$ & 10. & $\begin{array}{l}\text { a. Three donators do not enclosed copies of identities. } \\
\text { b. Total two donations are Rp100 Million and have been giving back to the country } \\
\text { while one donation is Rp1 Billion has not been returned. } \\
\text { c. There are four transactions are not recorded on RKDK because received in cash } \\
\text { and liability and have been expensed. } \\
\text { d. There is no answer for donation confirmations. }\end{array}$ & 4 \\
\hline \multirow[t]{4}{*}{9} & \multirow{4}{*}{$\begin{array}{l}\text { Partai Persatuan Pem- } \\
\text { bangngan (PPP) }\end{array}$} & 2. & Revenue interest on saving and tax are recorded in one line. & \multirow[t]{4}{*}{4} \\
\hline & & 7. & $\begin{array}{l}\text { There is difference amount between donations in DLPSK and LPPDK. The difference } \\
\text { is Rp4.5 Billion. }\end{array}$ & \\
\hline & & 13. & $\begin{array}{l}\text { The difference on expense (Rp4.5 Billion) because the mistake on candidate expense } \\
\text { records and double counting. }\end{array}$ & \\
\hline & & 14. & There is difference on expense of Rp5.000 because the mistake on recording. & \\
\hline \multirow[t]{3}{*}{10} & \multirow{3}{*}{$\begin{array}{lcc}\text { Partai } & \text { Hati } & \text { Nurani } \\
\text { Rakyat (Hanura) } & \end{array}$} & 2. & Revenues are cash not included in RKDK. & \multirow[t]{3}{*}{3} \\
\hline & & 10. & Some of personal donators do not enclosed copies of identities. & \\
\hline & & 14. & Some differences between date of records and supporting documents & \\
\hline \multirow[t]{5}{*}{11} & \multirow[t]{5}{*}{$\begin{array}{l}\text { Partai } \\
\text { (PBB) }\end{array}$} & 2. & $\begin{array}{l}\text { a. There is no supporting document for the donation of Rp430 Million. } \\
\text { b. Accommodation and socialization expense do not have detail records } \\
\text { c. There is Rp250 Million cash revenue not included in RKDK. }\end{array}$ & \multirow[t]{5}{*}{10} \\
\hline & & 6. & There is transpose error on donation. It is Rp430 M but recorded Rp340 M. & \\
\hline & & 10. & $\begin{array}{l}\text { a. One entity donator does not enclosed copies of identities. } \\
\text { b. Good donations (flags) are no supporting documents (receiving receipt). }\end{array}$ & \\
\hline & & 11. & The expenses are not categorized as classified on DAPDK. & \\
\hline & & 13. & $\begin{array}{l}\text { a. The operation expense is recorded Rp0 on DAPDK and Rp68.5 Million on } \\
\text { LPPDK } \\
\text { b. The capital expense is recorded Rp0 on DAPDK and Rp759 Million on LPPDK } \\
\text { c. The other expense is recorded Rp0 on DAPDK and Rp80.8 Million on LPPDK }\end{array}$ & \\
\hline
\end{tabular}




\begin{tabular}{|l|l|l|l|l|}
\hline 12 & \begin{tabular}{l} 
Partai Keadilan dan \\
Persatuan Indonesia \\
\cline { 3 - 4 }
\end{tabular} & 2. & The expense and revenue of fund campaign accounting are not recorded on RKDK \\
\hline
\end{tabular}

If we look at agreed upon procedures based on the findings on each procedures, we will find out different angle (see table 5). Procedure 1 is no finding. Record the fund campaign reporting receipt from political parties. It is obvious that all political parties submit the fund campaign report. If they were not submit, they will be punished. The success candidate will not be legalized and vowed. This is the ultimate goal and the political party will not play around with this regulation.

Procedure 2 is tracing all revenue and expenses on special bank campaign account (RKDK) to revenue and expenses report (LPPDK). It gets nine findings from six political parties. The majority comes from that political parties do not put the donation through the special account (RKDK) but directly expense it. This could happen due to the time limit and pressure on campaign. It could be that bank is closed on the weekend while they have to spend a lot in the weekend time for campaign (especially on meeting and campaign rallies). The second mistake happens on the way of recording interest revenue and tax. It is not so clear on KPU rules form to put those things(3).

Special campaign bank account is audited on procedure 3 and 4 None finding found. All political parties obey to have special bank account for campaign party. The bank categorized is followed. The regulation on this part is clearly stated on KPU Regulation no. 17, 2013 on part 4 that stated all the campaign fund has to be put in special bank account. Part $14-16$ are specially set up the regulation on the campaign fund such as that special bank account used solely for fund campaign and separated from campaign fund and personal fund. The source of the fund and the report of the fund in special bank account have to be reported to KPU on timely basis. This report is submitted early before the final fund campaign hand to public accountant. The political party is followed the rule without mistake.

Procedure number 5 is about the classification of donation. Only two findings are from two political parties. The fund campaign revenue mistakes on the classification caused by political party records the cash donation as the good donation. The amount of this mistake is material as 1 billion Rupiah. The other mistake due to the political party is not supported the donation with legal identity and taxpayer identity, so they have to surrender the donation to country.

The correctness of mathematics count has one mistake (procedure number 6). Transpose error is happen here. The political party recorded the donation of 340 million rupiah that supposed to be 430 million rupiah. It is negligence that put error on difference donation of 90 million rupiah. It may happen because the political party do it manually so that no link between reports.

Political party has to submit two fund campaign revenue reports on the campaign period to KPU. In the end of the campaign, political party has to submit final fund campaign report. Summarize of all the revenue and expenditure report will be on final fund campaign report. Thus two fund campaign reports should be the same on the final fund campaign report (procedure no. 7). There are three political parties disobey this. It could be happened again because the political party do it manually so that no link between reports.

The check between sums of revenue on each donation with the accumulation of revenue on each donation contributes one mistake (procedure no.8). There is mathematical error on counting the donation. One can be traced from the error on counting the candidates' donation. This probably happen because they prepare manually.

According to the KPU rule no. 17, 2013 on part 19 that all donations must be supported by legal identity and tax identity. On part 26, the KPU rule no. 17, 2013 stated that if there is donation that not supported by identity, then the political party could not use the fund and have to give to the country. It is procedure number 9 . Three illegal donations give to the country while others do not clear the treatment regarding this. It is zero finding because the mistake on this number covers on procedure 10.

The fitness between revenue donation report suits with identities contributing 13 mistakes (procedure no. 10). The same problems arise due to personal donation and company donation is not supported by legal and tax identity. Every donator has to submit declaration letter and identity. Few of them not submit declaration letter. Two political parties use the money donation directly without put in on the special account. The positive confirmation letter to donator gives a clue on the mistake of donation amount. There is one political party whom donators do not reply all of confirmation letters. Others have no problem with confirmation letters. There are two service donations. They could not compare with fair value due to no supporting document such as price quotation. Others do not have service and good donation and do not apply this rule.

The inconsistency classification between the activities and expense of campaign report (DAPDK) and revenue and expenses of campaign record (LPPDK) contributes two mistakes (procedure 11). Expenditures for the campaign are divided into three major segments which are operational, capital expenditure, and others expenditure. The expenses are divided into closed meeting, open meeting, advertisement, distribute of campaign goodies, campaign setup and other activities that do not violate law. There is no mistake of all mathematics count on expenditures (procedure 12).

The comparative between expenditure fund campaign report with revenue and expense fund campaign report have seven mistakes (procedure 13). Political parties do not put the expenditure on special account and the expenditures of candidates do not included on expenditure report. The other mistake is political party does not report expenditure on expenditure fund campaign report but records on the revenue and expense fund campaign report. The other mistake comes from double counting.

Number 14 procedure is checking the accuracy on expense transactions and supporting documents. The mistake comes from the expenditure does not put on special account and the expenditure is not supported by documents such as invoice. There are 177 candidates that do not give the expenditure reports. There is political party that does not put the expenditure report of the candidate on the revenue and expense fund campaign report. Candidates do not submit the report could be because they are not winners and elected. The fair value measurement is kindly hard to followed because political parties have to get comparison table on several prices on the market.

There is no error on procedure 15. All political parties have submitted representation letter to KPU while giving all the documents to be audited. It is so obvious that the rule giving example and every time socialization, KPU remind of this letter.

There are 15 procedures. Only six procedures are no mistakes. The other nine procedures contain mistakes and only one political party is free from the mistake. When we see the mistakes are so variety from human error, no good understanding on KPU Rule no. 17, 2014 until no standard on candidates campaign report. The summary of the procedures is shown on table 6 .

The mistakes could probably because no standard on the human resources, not enough training on the fund campaign report, not enough time to submit report, and no software to help to do it. The training of fund campaign report is done by KPU for accountants of the political party. The accountants of the political party have to teach to the candidates. The training of trainers is done by Indonesian Chartered Accountants (IAI) collaboration with KPU. The political party has to submit the report a week after the campaign is over. It probably is not all expenditures being recorded. There 
are still mistake on counting due to the counting manually and no integration between reports. This could overcome by using software.

Table 6: Audited Fund Campaign ReportAgreed Upon Procedures

\begin{tabular}{|c|c|c|c|c|c|c|c|c|c|c|c|c|c|c|c|c|c|}
\hline \multirow[b]{2}{*}{ № } & \multirow[b]{2}{*}{ Political Parties } & \multicolumn{16}{|c|}{ Findings on Procedures Number } \\
\hline & & 1 & 2 & 3 & 4 & 5 & 6 & 7 & 8 & 9 & 10 & 11 & 12 & 13 & 14 & 15 & Total \\
\hline & Parai Nasional Demokrat (Nasdem) & - & - & - & & - & - & 1 & 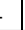 & . & 2 & 1 & - & 2 & - & & \\
\hline 2 & Parai Kebangkitan Bangsa (PKB) & . & 2 & . & - & . & - & . & . & . & . & . & . & . & . & . & \\
\hline 3 & Parai Keadilan Sejahtera (PKS) & . & 1 & . & - & . & - & . & 1 & . & 2 & . & . & . & . & . & \\
\hline 4 & Partai Demokrasi Indonesia Perjuangan (PDIP) & . & . & . & - & . & $\varepsilon^{-}$ & . & . & . & 1 & . & . & . & & . & \\
\hline 5 & Parai Golongan Karya (Golkar) & . & . & . & . & 1 & - & - & - & - & - & - & - & - & - & - & 1 \\
\hline 6 & Parai Gerakan Indonesia Raya (Gerindra) & . & . & . & . & . & - & . & - & . & . & - & . & . & . & - & \\
\hline 7 & Parai Demokrat (PD) & . & . & . & . & 1 & . & 1 & . & . & 1 & . & . & . & & . & \\
\hline 8 & Parai Amanat Nasional (PAN) & . & . & . & - & - & - & . & - & . & 4 & . & - & . & - & - & \\
\hline 9 & Partai Persatuan Pembangngan (PPP) & - & 1 & . & . & . & - & 1 & - & . & . & . & . & 1 & & - & \\
\hline 10 & Partai Hat Nurani Rakyat (Hanura) & . & 1 & . & . & . & - & . & - & . & 1 & . & . & . & & - & 3 \\
\hline 11 & Partai Bulan Bintang (PBB) & . & 3 & . & $\cdot$ & . & 1 & . & - & . & 2 & 1 & . & 3 & . & - & 10 \\
\hline 12 & Parai Keadilan dan Persatuan Indonessia (PKPI) & - & 1 & . & . & - & . & . & 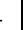 & . & - & . & . & & - & . & 2 \\
\hline & Total & & 9 & & & 2 & & 3 & & & 13 & 2 & & 7 & & & 42 \\
\hline
\end{tabular}

\subsection{Compliance Audit}

Based on the agreed upon procedures, the auditor is doing compliance audit. Basically the auditor is judging whether the political party complies with the stated rule on fund campaign reporting. It is only stated compliance and not compliance but not giving positive assurance.

It is stated on the auditor letter. They are doing agreed upon procedures based on auditing standard by IAPI. The adequate coverage from the procedures is KPU responsibilities. As consequence, the auditor will not attest the procedures. They are not doing attestation or general audit to give assurance on revenue and expense of fund campaign reporting (LPPDK). There is suggestion sentences mention by auditor that if they ask to do more procedures, it might cover and report more to KPU. The auditor does not have any obligation to updating the report after the report date.

Basically the compliance audit is based on the finding on agreed upon procedures. They are divided into three segments on eleven statements as stated bellows:

A. General

1. Report coverage

2. Record and report timing

B. Revenue and Expense of Fund Campaign Reporting (LPPDK)

3. Special Fund Campaign Bank Account (RKDK)

4. The limitation on maximum donation

5. The on time submission reporting to KPU

6. Treatment on illegal donation

7. The source of campaign fund from political party and candidate

C. Initial Revenue and Expense of Fund Campaign Reporting and Special Fund Campaign Bank Account (RKDK)

8. The on time submission initial revenue and expense of fund campaign reporting

9. The detail of special fund campaign account (RKDK)

10. The special fund campaign account reporting

11. The initial revenue and expense of fund campaign reporting

The auditor stated on eleven statements as compliance and not compliance based on findings and ruled stated. When auditor stated not compliance then the auditors will give underlying reasonable reason. There are seven political parties with clean compliance and five political parties have no compliance on certain statements. The summary can be seen on table 7 .

Partai Keadilan Sejahtera have two no compliances. First, some donations are spending directly without putting on special fund campaign account (statement 3 ) and second, there are no supporting documents of donators (statement 6). Partai Amanat Nasional have two no compliances as the same as Partai Keadilan Sejahtera.
The reason that some donations are spending directly without putting on special fund campaign account (statement 3 ) and there are no supporting documents of donators (statement 6). The some donations have giving back to the country while there is one donation still keep on and used for campaign.

Partai Persatuan Pembangunan is not compliance on report coverage. There is expense without detail recording. Partai Bulan Bintang gets three no compliances. It comes from one candidate does not submit the supporting document for the revenue and expense of candidates' fund campaign (statement 1), some donations are spending directly without putting on special fund campaign account (statement 3), and finally due to time frame on reporting (statement 11).

Partai Keadilan dan Persatuan Indonesia is having two no compliances. The first one is (statement 2), because PKPI does not record the expense of campaign fund candidates on revenue and expense of fund campaign reporting (LPPDK). The second is just like any other on statement 3 that some donations are spending directly without putting on special fund campaign account.

Although there are 42 findings on agreed upon procedures, but there are only ten non compliances. The auditor does not state the double counting, transpose error, mistake counting as no compliance. It is probably that the finding can be corrected and restatement and may not be material according to auditor valuation. The fair value valuation is not based to no compliance either. It may be understandable because there is no example on how to figure out the fair value. The auditors have the supporting documents on the expenditures.

No compliance basically divided into candidates, donators, and time frame. The candidate contributes no compliance due to not submitting the supporting document on expenses (statement 1) and is not recorded on the revenue expense fund campaign of political party report (statement 2). The auditor give no compliance on donation spending directly without put in special account, the donation without supporting documents, and the treatment of illegal donation as stated on statement 3 and 6 . The time frame of revenue expense fund campaign of political party should be ended on $2^{\text {nd }}$ march, 2014 while the political party ended early on February 27, 2014.

Table 7: Summary of Compliance Audit

\begin{tabular}{|c|c|c|c|c|c|c|c|c|c|c|c|c|c|}
\hline \multirow[b]{2}{*}{ No } & \multirow[b]{2}{*}{ Political Parties } & \multicolumn{12}{|c|}{ Compliance Audit } \\
\hline & & 1 & 2 & 3 & 4 & 5 & 6 & 7 & & 9 & 10 & 11 & Total \\
\hline 1 & Partai Nasional Demokrat (Nasdem) & - & - & - & - & - & - & - & - & - & - & -1 & - \\
\hline 2 & Partai Kebangkitan Bangsa (PKB) & - & - & - & - & - & - & - & - & - & - & - & - \\
\hline 3 & Partai Keadilan Sejahtera (PKS) & - & - & $\mathrm{NC}$ & - & - & NC & - & - & - & - & - & 2 \\
\hline 4 & Partai Demokrasi Indonesia Perjuangan (PDIP) & - & - & - & - & - & - & - & - & - & - & - & - \\
\hline 5 & Partai Golongan Karya (Golkar) & - & - & - & - & - & - & - & - & - & - & - & - \\
\hline 6 & Partai Gerakan Indonesia Raya (Gerindra) & - & - & - & - & - & - & - & - & - & - & - & - \\
\hline 7 & Partai Demokrat (PD) & - & - & - & - & - & - & - & - & - & - & - & - \\
\hline 8 & Partai Amanat Nasional (PAN) & - & - & NC & - & - & NC & - & - & - & - & - & 2 \\
\hline 9 & Partai Persatuan Pembangngan (PPP) & NC & - & - & - & - & - & - & - & - & - & - & 1 \\
\hline 10 & Partai Hati Nurani Raky at (Hanura) & - & - & - & - & - & - & - & - & - & - & - & - \\
\hline 11 & Partai Bulan Bintang (PBB) & $\mathrm{NC}$ & - & $\mathrm{NC}$ & - & - & - & - & - & - & - & NC & 3 \\
\hline 12 & Partai Keadilan dan Persatuan Indonesia (PKPI) & - & $\mathrm{NC}$ & $\mathrm{NC}$ & - & - & - & - & - & - & - & -1 & 2 \\
\hline & Total & 2 & 1 & & - & - & 2 & - & - & - & - & 1 & 10 \\
\hline
\end{tabular}

${ }^{*} \mathrm{NC}=$ Not Compliance

\subsection{Chi-Square Test}

The goodness of fit test (chi-square) analysis has been used to test the quantitative data from agreed upon procedures of the political parties. The findings are data used with the hypothesis:

Ho $=$ There are no difference findings between all political parties regarding the fund campaign report.

$\mathrm{Ha}=$ There are difference findings between all political parties regarding the fund campaign report.

The result finding can be seen on table 8 . The critical value for $\mathrm{x}^{2}$ is 12.592 and the counting value for $x^{2}$ is 5.5. Based on the finding that the counting value is smaller than critical value $(5.5<12.592)$, it can be concluded that Ho is accepted. The conclusion is there 
are no differences findings between all political parties regarding fund campaign report.

Table 8: Frequencies

\begin{tabular}{|l|r|r|r|}
\hline \multicolumn{1}{|l|}{ Findings } & Observed N & Expected N & Residual \\
\hline .00 & 1 & 1.7 & -.7 \\
\hline 1.00 & 1 & 1.7 & -.7 \\
\hline 2.00 & 3 & 1.7 & 1.3 \\
\hline 3.00 & 1 & 1.7 & -.7 \\
\hline 4.00 & 4 & 1.7 & 2.3 \\
\hline 6.00 & 1 & 1.7 & -.7 \\
\hline 10.00 & 1 & 1.7 & -.7 \\
\hline Total & 12 & & \\
\hline
\end{tabular}

\begin{tabular}{|l|r|}
\hline \multicolumn{2}{|c|}{ Test Statistics } \\
\hline & \multicolumn{2}{r|}{ findings } \\
\hline Chi-Square & $5.500^{\mathrm{a}}$ \\
\hline Df & 6 \\
\hline Asymp. Sig. & .481 \\
\hline
\end{tabular}

a. 7 cells $(100.0 \%)$ have expected frequencies less than 5 . The minimum ex pected cell frequency is 1.7 .

There are no difference findings among the political parties. The result may because almost all the political parties have findings, only one is not. On the average, all political parties need to pay attention, working more on fund campaign report on the findings found.

\subsection{Result}

The result supported agency theory that agent (political parties) and principal (voters) may not aligned because asymmetry information on fund campaign reporting. Agreed upon procedures shown there are irregularities on many aspects but the auditors still stated comply on those items. Based on the findings, this research supports that the level of knowledge, quality audit, and the audit report are difference between political parties, KPU and public accountants(13). The research supports the on reducing quality on audit(15). This is shown from same mistakes findings have been getting different treatment among auditors.

All of political parties (100\%) submit the fund campaign reporting on time (procedure number 1 on agreed upon procedure). The submit rate result $(100 \%)$ is higher than $92 \%$ (14) because all political parties win the seats on general elections. Hakim (2014) found no compliance from 4 political parties while this research found no compliance from 5 political parties. The differences may happen because of detail coverage in this research observed on each compliance item while Hakim (2014) observed globally.

\section{Conclusion}

There are 15 procedures. Findings on agreed upon procedures are 42 mistakes from 9 political parties. The compliance audit found 10 errors from 5 political parties. The result of the review shows the weakness of fund campaign report. All political parties contribute for the findings equally based on the result of chi-square test. The weakness and findings comes from many forms that can be categorized as below:

1. Mathematical problem

a. Transpose error

b. Double counting

c. Sum error

2. Donation

a. The donators are not supported by legal identity

b. The donation without legal identity is not given back to country

3. Candidates

a. There are candidates not submitting fund campaign report b. The candidates do not give supporting documents on fund campaign report

4. Not following the KPU Rule no. 17, 2013

a. The fund is not placed in special account before used

b. There is error on placing expenditure segment

c. There is no consistency between one report to another report

Based on the weakness, KPU could overcome those with doing necessary steps, such as:

1. Building software for fund campaign reporting. The software will overcome mathematical problem (sum error, double counting, and transpose error) and there will be consistency between reports.

2. Intense training with stressing about the important of donation and supporting documents, candidates fund campaign report, special account, and KPU Rule no. 17, 2013.

3. Change the scope of audit. The auditors are not working only on revenue expense fund campaign reporting but cover the candidates fund campaign reporting because the candidates contribute the biggest revenue for campaign.

4. Expand the assignment of audit. The auditors are not working only on agreed upon procedures and compliance audit but doing more as fully audit. The auditors will do attestation and publish the opinion.

5. Follow up the findings. KPU should work on the findings and give punishment on necessary findings so that political parties know that KPU really enact on rule.

6. Stop doing off balancing reporting. KPU should stress to the political parties that all fund campaign should through the special bank fund campaign account, so that all transaction will be recorded and accountable.

The fund campaign reporting is gradually process to be more accountable, transparent, and credible. In the future when all commitment from stakeholders (KPU, Political Parties, Auditors, Accountants, and Public) put on the hard work in the process of fund campaign reporting, there is no doubt that the reports are not only formality and administrative. The good of fund campaign reporting will create good political party governance. It will address that the good political party governance will dismiss money politics. People will see that political party independent and transparent so that can be trust as accountable and credible.

\section{Acknowledgement}

This research work is supported by the competitive research scheme supported by Ministry of Research, Technology and Higher Education of the Republic of Indonesia.

\section{References}

[1] Manikas PM, Thorton LL. Political Parties in Asia Promoting Reform and Combating Corruption in Eight Countries. United States of America: National Democratic Institute for International Affairs (NDI); 2003

[2] Wikipedia. Komisi Pemilihan Umum. Wikipedia2017.

[3] KPU. KPU Rule No. 17. Pedoman Pelaporan Dana Kampanye Peserta Pemilihan Umum Anggota Dewan Perwakilan Rakyat, Dewan Perwakilan Daerah dan Dewan Perwakilan Rakyat. Jakarta, Indonesia: Komisi Pemiliihan Umum; 2013.

[4] KPU. KPU Rule No.24. Pedoman Audit Laporan Dana Kampanye Peserta Pemilihan Umum Anggota Dewan Perwakilan Rakyat, Dewan Perwakilan Daerah, dan Dewan Perwakilan Rakyat Daerah. Jakarta, Indonesia: Komisi Pemilihan Umum; 2013.

[5] KPU. KPU Rule No. 12. Perubahan atas Peraturan Komisi Pemilihan Umum Nomor 24 Tahun 2013 tentang Pedoman Audit Laporan Dana Kampanye Peserta Pemilihan Umum Anggota 
Dewan Perwakilan Rakyat, Dewan Perwakilan Daerah, dan Dewan Perwakilan Rakyat Daerah. Jakarta, Indonesia: Komisi Pemilihan Umum; 2014.

[6] KPU. KPU Decision Letter No 368. Pedoman Audit Laporan Dana Kampanye Peserta Pemilihan Umum Anggota Dewan Perwakilan Rakyat, Dewan Perwakilan Daerah, dan Dewan Perwakilan Rakyat Daerah. Jakarta, Indonesia: Komisi Pemilihan Umum; 2014.

[7] Eisenhardt KM. Agency Theory: An Assessment and Review. The Academy of Management Review. 1989;14(1):57-74.

[8] Investopedia. Agency Costs. Investopedia2017.

[9] Raja RJL. Small Change: Money, Political Parties, and Campaign Finance Reform. Ann Arbor: University of Michigan Press; 2008.

[10] IFES. Republic of Indonesia On-Site Technical Assistance Mission Project Report. Internal Foundation for Election System, 2000.

[11] Hakim JA. Kajian Atas Proses Pengauditan Laporan Dana Kampanye Peserta Pemilihan Umum Legislatif. Internship Report. Jakarta: University of Indonesia, 2014.

[12] Krumholz S. Campaign Cash and Corruption: Money in Politics, Post-Citizen United. Social Research. 2013;80(4):1119-34.

[13] Darmoko HW, R D, editors. Audit Dana Kampanye Pemilihan Umum Kepala Daerah Menurut Persepsi Partai Politik, Komisi Pemilihan Umum Daerah dan Auditor Kantor Akuntan Publik. 3rd Economics \& Business Research Festival; 2014; Salatiga: Economics and Business Faculty of Kristen Satya Wacana University.

[14] Sugiwa I, Arifah MP, Farobi HK. Analisa Tingkat Kepatuhan Pelaporan Dana Kampanye Partai Politik Peserta Pemilu Berdasarkan Hasil Audit Laporan Dana Kampanye di Provinsi Bali pada Pemilu Legislatif 2014. Ekonomi dan Bisnis. 2015:35-40.

[15] Antony IS. Analisis Perilaku Reduksi Kualitas Audit KAP X dalam Melaksanakan Audit Berdasarkan Prosedur yang Disepakati (Studi Kasus pada Audit Dana Kampanye Pemilu Legislatif Tahun 2014 Partai X). repository of Airlangga University [Internet]. 2014 November $5 . \quad$ Available from: http://repository.unair.ac.id/id/eprint/5460.

[16] Anjalline I, Anggraini R, Indrayati R. Electoral Campaign Fund Regulatory Responsibilities as A Member of Legislative Candidate by Law Number 8 in 2012 Election of Members of The House of Representatives, The House of Representatives and The House of Representatives. e-Journal Lentera Hukum. 2014;I(1):42-53.

[17] Saputra R. Mendorong Transparansi dan Akuntabilitas Dana Kampanye Melalui Pembatasan Transaksi Keuangan Tunai. Jurnal Pemilu dan Demokrasi. 2013;6:1-21.

[18] Palda F, Palda K. The Impact of Campaign Expenditures on Political Competition in the French Legislative Elections of 1993 Public Choice. 1998;94(1-2):157-74.

[19] Irtanto. Political Behavior of Voters on Mayoral Election of Kediri East Java Indonesia. Academic Research International. 2014;5(2):309-24.

[20] Ferdinand P. Party Funding and Political Corruption in East Asia: The Cases of Japan, South Korea and Taiwan. In: Burnell P, Ware A, editors. Building Democracies on the Basis of Capitalism: Towards an East Asian Model of Party Funding. Manchester: Manchester University Press; 1998. p. 55-69.

[21] Abdillah LA. IT Based Social Media Impacts on Indonesia General Legislative Elections. American Academic \& Scholarly Research Journal. 2014;6(4):360-75.

[22] Trihartono A. Beyond Measuring the Voice of the People: The Evolving Role of Political Polling in Indonesia's Local Leader Elections. Southeast Asian Studies. 2014;3(1):151-82. 